\title{
Editorial
}

\section{GÊNERO: DESNATURALIZAÇÃO DA DIFERENÇA E COMBATE À INTOLERÂNICA}

Talita Nunes Silva Gonçalves ${ }^{1}$

Os estudos de gênero têm início na década de 1960 na Europa e nos Estados Unidos como resultado do impacto dos movimentos libertários que questionavam os valores dominantes e lutavam pelo respeito às minorias. Contudo, embora utilizado por outras áreas do conhecimento, como a Psicologia, a emergência do gênero como conceito pertinentemente empregado nas pesquisas em História se dará apenas a partir dos anos 1980. Até então, faltava ao gênero a credibilidade necessária entre os historiadores. Tal descrédito era justificado pela acusação feita ao conceito de que o mesmo não seria operacional. Será a historiadora e feminista norte-americana Joan Scott que fará, a nosso ver, a devida e decisiva defesa do gênero diante de seus pares. Em artigo publicado em 1986, Gender: a useful category of historical analysis, Scott defendia a operacionalidade do gênero, definindo-o como modo primeiro de significar as relações de poder, rejeição ao determinismo biológico, defesa do caráter essencialmente social das distinções constituidas sobre o sexo e da dimensão relacional entre homens e mulheres.

A partir desta definição tecida por Joan Scott, ainda hoje amplamente empregada, o uso do gênero pela História ganha impulso. Inicialmente "associado e utilizado principalmente pelas historiadoras das mulheres" (CUCHET, 2007, p. 18), atualmente o conceito é adotado seja pela 'História 
das Mulheres', pela 'História de Gênero' ou pelo Men's Studies. Empregado em todas as temporalidades da pesquisa histórica e muito utilizado por esta e outras disciplinas, o conceito de gênero conquistou o seu lugar e a legitimidade na academia. Não só na academia, mas também nas mídias sociais e nos programas implantados por instituições e governos. No entanto, apesar disso e das conquistas obtidas pelo movimento feminista, as desigualdades de gênero ainda persistem. Tais desigualdades podem ser observadas na violência a qual as mulheres estão submetidas justamente pela condição de serem mulheres. A vulnerabilidade em que se encontram pode ser verificada no levantamento recente feito pela Thomson Reuters Foundation. Os cerca de 550 especialistas em temas femininos que colaboraram com a pesquisa apontaram os 10 paísesmembros da Organização das Nações Unidas (ONU) mais perigosos para as mulheres. ${ }^{2}$ Dentre eles, para a surpresa de muitos, figura na décima posição os Estados Unidos: tradicional defensor das liberdades democráticas e dos direitos humanos. Quanto ao Brasil, ainda que esteja ausente desta lista, o país - segundo reportagem da Revista $E_{x a m e}{ }^{3}$ - tem a quinta maior taxa de feminicídios do mundo.

Para desnaturalizar a violência contra a mulher, as demais discriminaçóes a que estão submetidas, bem como a violência e segregação motivada pela identidade de gênero manifesta pelos indivíduos, é necessário que os debates em torno do conceito estejam presentes no ambiente escolar e acadêmico. Só através da educação, ou seja, da conscientização acerca das desigualdades existentes na sociedade - dentre elas, as de gênero - e da compreensão do modo pelo qual são constituídas, será possível formar cidadãos mais empáticos e respeitosos às diferenças. Entretanto, a inclusão das discussões sobre o gênero na sala de aula tem suscitado reaçóes conservadoras de parte da sociedade brasileira que, ao interpretar de modo equivocado o intuito destes debates, acabam por considerá-los promulgadores de uma pretensa ideologia de gênero'. Para este segmento da sociedade, as reflexões em torno do conceito nas escolas, nas universidades e nas mídias teriam o objetivo de influenciar, sobretudo,

2 Segundo reportagem do Estadão, dentre os quesitos de periculosidade que foram considerados pela pesquisa se encontram a vulnerabilidade à violência sexual e não sexual, assim como na área da saúde e da economia. Disponível em https://internacional.estadao.com.br/noticias/ geral,pesquisa-revela-os-10-paises-mais-perigosos-para-as-mulheres,70002370639 . Acesso em $26 / 08 / 2018$ às 14 h00.

3 Disponível em https://exame.abril.com.br/brasil/taxa-de-feminicidios-no-brasil-e-a-quintamaior-do-mundo/. Acesso em 28/08/2018 às 16 h00. 
crianças e jovens. E, ao influenciá-los, os levar a adotar um gênero diferente daquele a eles atribuído no nascimento em decorrência do sexo biológico. Tal inferência explica as manifestaçóes ocorridas em 2017 contra a presença da filósofa Judith Butler no Brasil. No entanto, tal interpretação é equivocada.

O que o debate em torno do conceito propõe é a desnaturalização da diferença e o combate à intolerância. Por meio do entendimento de que as diferenças sociais entre homens e mulheres não são inatas, mas fruto da interpretação que uma determinada sociedade faz do masculino e do feminino, o gênero permite desconstruir a visão tradicional de que a mulher é 'naturalmente' propensa aos serviços domésticos, à submissão ao homem e à manifestação de determinadas habilidades. Do mesmo modo, o gênero permite desmistificar a percepção do homem como não dado às emoções, voltado para as atividades externas à casa e portador de um comportamento caracterizado invariavelmente pela virilidade. Além disso, o gênero e mais especificamente a teoria da performatividade de gênero de Judith Butler (2015) - que em nenhum momento professa a inexistência da diferença entre os sexos - chama a atenção para o fato de que há pessoas que não conseguem se adequar às expectativas que a sociedade atribui ao gênero que lhes confere. Tal impossibilidade de adequação e a segregação dela decorrente geram sofrimento e, não raro, violências físicas que podem se tornar letais. A compreensão da existência de pessoas que estão impossibilitadas de se adequar as expectativas de gênero da sociedade visa, portanto, suscitar o respeito e minar a intolerância e violência desferida contra esses indivíduos. O gênero é, assim, um importante conceito que visa permitir uma existência com mais respeito à diferença e, por conseguinte, que estimula a vivência das liberdades democráticas.

Os artigos que compóem esse dossiê partem da perspectiva de gênero ao abordar o papel desempenhado pelas mulheres nas sociedades antigas, a forma como as tratam os livros didáticos que contemplam a História Antiga, a construção dos papéis de gênero na documentação, assim como os desvios aos ideais de comportamento feminino e masculino vigentes na Antiguidade. Tais textos, consequentemente, nos permitem observar semelhanças e diferenças no modo como construímos e definimos os papeis de feminino/masculino e a forma como as sociedades da Antiguidade o fizeram. As diferenças que este exercício de comparação ressalta permitem exemplificar e compreender a definição do gênero como o modo como uma determinada sociedade interpreta as diferenças baseadas no sexo. Esta definição nos leva a compreender que os 
comportamentos tidos como tipicamente femininos ou masculinos não são os mesmos em todos os lugares e em todas as temporalidades, contribuindo assim para a reafirmação do compromisso que a teoria de gênero professa: desnaturalizar a diferença e combater a intolerância.

\section{REFERÊNCIAS}

BUTLER, Judith. Problemas de gênero: Feminismo e subversão da identidade. Rio de Janeiro: Civilização Brasileira, 2015.

SCOTT, Joan. 'Gênero: uma categoria útil para análise histórica'. S.O.S. Recife: 1991.

SEBILLOTTE CUCHET, Violaine.'Les antiquistes et le genre'. In: SEBILLOTTE CUCHET, Violaine; ERNOULT, Nathalie (orgs.). Problèmes du genre en Grèce Ancienne. Paris: Publications de la Sorbonne, 2007. 